\title{
Macrobenthic recovery from hypoxia in an estuarine tidal mudflat
}

\author{
C. Van Colen ${ }^{1, *}$, F. Montserrat ${ }^{2,3}$, M. Vincx ${ }^{1}$, P. M. J. Herman ${ }^{2}$, T. Ysebaert ${ }^{2}$, \\ S. Degraer ${ }^{1,4}$ \\ ${ }^{1}$ Ghent University, Department of Biology, Marine Biology Section, Krijgslaan 281/S8, 9000 Ghent, Belgium \\ ${ }^{2}$ Netherlands Institute for Ecological Research (NIOO-KNAW), Centre for Estuarine and Marine Ecology, PO Box 140, \\ 4400 AC Yerseke, The Netherlands \\ ${ }^{3}$ Delft University of Technology, Faculty of Civil Engineering and Geosciences, Hydraulics Section, PO Box 5048, \\ 2600 GA Delft, The Netherlands \\ ${ }^{4}$ Management Unit of the Mathematical Model of the North Sea, Royal Belgian Institute of Natural Sciences, Gulledelle 100, \\ 1200 Brussels, Belgium
}

\begin{abstract}
Macrobenthic recolonisation patterns after complete defaunation resulting from experimentally induced hypoxia were investigated in a polyhaline, estuarine mudflat. Based on simultaneous sampling of biotic and environmental variables in replicated $16 \mathrm{~m}^{2}$ control and defaunated plots, with a high resolution in time during $6 \mathrm{mo}$, the ecological interactions related to the macrobenthos reassembly were elucidated. Colonisation was predominantly determined by juvenile recruitment, and 3 successional stages were identified, each characterised by different species assemblages and environmental characteristics. During recovery, a shift in functional group dominance from mobile surface deposit feeders to tube-dwelling surface deposit feeders to biodestabilising taxa occurred, while their proportional dominance remained quite stable in the control plots throughout the experiment. Species colonisation patterns of later colonists revealed positive interactions with early colonising opportunistic tube-building polychaetes Pygospio elegans, while later successional species (Heteromastus filiformis, Macoma balthica) adversely affected the stable, favourable conditions created by the tube-building infauna. Transitions between different successional stages were related to recruitment of species, changes in environmental characteristics (oxygenation state of the sediment), direct and indirect ecological interactions (bio[de]stabilisation, exploitation competition for food). In general, our study suggests that macrobenthic reassembly after hypoxia is related to different types of interactions, all acting in a unique manner. Hence, macrobenthic successional dynamics in a tidal mudflat habitat should be considered as a dynamic process, related to resource availability, natural temporal variation, life history traits (e.g. opportunistic behaviour) and bio-engineering capacities of the colonising species.
\end{abstract}

KEY WORDS: Macrobenthos (re)colonisation · Succession • Physical-biological interactions . Exploitation competition for food · Tidal mudflat · Westerschelde estuary

\section{INTRODUCTION}

Habitat loss and degradation result in an alarming decrease of biodiversity and constitute a major, widespread environmental problem. Since $\sim 60 \%$ of the world population lives along estuaries and coasts (Lindeboom 2002), marine benthic habitats are extremely vulnerable to different anthropogenic disturbance pressures, such as dredging and dredge disposal (e.g. Newell et al. 1998), bottom trawling fisheries (Thrush \& Dayton 2002), altered tidal regimes (Van Colen et al. 2006), toxic chemicals (Lenihan et al. 2003) and eutrophication (Cloern 2001). These disturbances can lead to partial or even complete macrobenthic mortal- 
ity in marine sediments (Thrush \& Dayton 2002, references therein). Such mortalities are particularly frequent in coastal seas, tidal flats and estuaries (Beukema et al. 1999), where the defaunated areas can cover several $\mathrm{km}^{2}$ (Diaz \& Rosenberg 1995). In estuarine tidal flat habitats, macrobenthic organisms fulfil several key roles in benthic remineralisation processes (Herman et al. 1999), sediment transport processes (Paterson \& Black 1999) and pelagic food chains, being an important food source for epibenthic crustaceans, fish and birds (Hampel et al. 2004). Due to their essential role in the estuarine ecosystem functioning, even local extinction of the benthos can have dramatic consequences (e.g. Beukema \& Cadée 1996). Once the disturbance(s) that cause mortality abate or disappear, macrobenthic recovery may occur.

Pearson \& Rosenberg (1978) found a gradual succession of macrobenthic community recovery along gradients of decreasing disturbance from a peak in abundance dominated by superficially living opportunistic species to a community with stable abundances of deeper burrowing species. The Pearson-Rosenberg model was developed using data from macrofaunal community dynamics after organic enrichment in subtidal, stable (i.e. low hydrodynamical stress) muddy sediments. However, this model is now widely considered as a general qualitative model of macrobenthic recovery from severe disturbances. Connell \& Slatyer (1977) postulated 3 generalised models of recovering communities based on interactions between early (i.e. pioneering) and later colonists. Early colonists can promote the establishment of later colonists (facilitation model), reduce the establishment of later colonists (inhibition model) or have little or no effect on the establishment of later colonists (tolerance model). These interactions can be direct and/or indirect (e.g. predation, interference competition, exploitation competition; e.g. Benedetti-Cecchi 2000, Wootton 2002). Additionally, as the spatial scale of disturbance will influence recovery dynamics (Norkko et al. 2006, references therein), recolonisation and succession mechanisms are scale-dependent processes.

A Pearson-Rosenberg type of macrobenthic recovery, consisting of different successional stages and clear opportunistic responses, has not always been observed in the few large-scale recolonisation studies in tidal flat habitats (e.g. Thrush et al. 1996, Beukema et al. 1999). Furthermore, the mechanisms of succession are not fully understood. Facilitative, inhibitory, as well as no interactions between earlier and later colonists have been reported and suggested from smaller-scale manipulative experiments (e.g. Gallagher et al. 1983, Whitlatch \& Zajac 1985, Thrush et al. 1992, Bolam et al. 2004). Distribution of macrobenthos in estuaries strongly depends on physical characteris- tics such as grain size, bed level and hydrodynamics (e.g. Herman et al. 2001, Ysebaert et al. 2003). Moreover, physical-biological interactions can change these characteristics, e.g. due to biodestablisation (by bioturbators, e.g. adult bivalves, large polychaetes) or biostabilisation (e.g. by microphytobenthos, reef-forming epifauna) of the sediment. This, in turn, has been shown to structure benthic populations (Bolam \& Fernandes 2003, van Wesenbeeck et al. 2007, Volkenborn \& Reise 2007). It can therefore be assumed that physical-biological interactions will also affect macrobenthic recolonisation dynamics, but the role of such interactions in macrobenthic reassembly remains poorly understood.

In this study, we examined macrofaunal recolonisation dynamics during one recruitment season based on sampling of both environmental and biotic changes in large experimentally replicated defaunated plots with a high temporal resolution. Based on this integrative approach, we investigated (1) whether macrobenthic recovery patterns in an intertidal mudflat resemble the Pearson-Rosenberg model, and (2) whether the macrobenthic recovery pattern is related to biological and physical-biological interactions between earlier and subsequent successional assemblages.

\section{MATERIALS AND METHODS}

Study site. The experiment was conducted at Paulinapolder, a tidal flat habitat located along the southern shore of the polyhaline part of the Westerschelde estuary, The Netherlands (512 $\left.21^{\prime} 24^{\prime \prime} \mathrm{N}, 3^{\circ} 42^{\prime} 51^{\prime \prime} \mathrm{E}\right)$. The mudflat has a gentle slope and a mean tidal range of $3.9 \mathrm{~m}$, with a semidiurnal regime. A homogeneous study site $(45 \times 45 \mathrm{~m})$, sheltered from waves and strong tidal currents associated with the main tidal channel at the mudflat, was selected based on environmental and biotic data collected in December 2004 (Table A1 in Appendix 1, available as Supplementary Material at http://www.int-res.com/articles/suppl/m371p031_app. pdf). The macrofaunal community at the study site consists of 18 macrobenthic species ( 30000 ind. $\mathrm{m}^{-2}$, $68 \mathrm{~g}$ ash-free dry weight [AFDW] $\mathrm{m}^{-2}$, ShannonWiener diversity index $H^{\prime}=1.87$ ) and is numerically dominated by 6 species, comprising $\sim 85 \%$ of the total macrobenthic abundance: the polychaetes Heteromastus filiformis, Pygospio elegans, Aphelochaeta marioni and Malacoceros tetracerus, tubificid oligochaetes and the bivalve Macoma balthica. However, due to their relatively small size, these polychaetes and oligochaetes do not contribute greatly to the total biomass $(\sim 23 \%)$; the bivalves Cerastoderma edule and Macoma balthica account for $\sim 76 \%$ of the total biomass (Appendix 1, Table A1). 
Experimental design, sampling and laboratory treatment. Three replicate $4 \times 4 \mathrm{~m}$ defaunated and control plots were randomly positioned within the study site, at least $5 \mathrm{~m}$ from each other. Based on scaledependent colonisation studies in tidal flats (e.g. Günther 1992) this scale was considered efficient (1) to minimise bias in successional dynamics through direct immigration by adult and juvenile organisms from the surroundings and (2) to allow frequent monitoring without disturbance of the experimental plots (see below). Plots were defaunated by covering the sediment with a water-proof polyethylene sheet $0.1 \mathrm{~mm}$ thick) and a tarpaulin sheet $\left(140 \mathrm{~g} \mathrm{~m}^{-2}\right)$ and digging in the edges up to $30 \mathrm{~cm}$, following Beukema et al. (1999) and Dittmann et al. (1999). On 30 March 2005, 40 d after covering, both layers were removed but the $30 \mathrm{~cm}$ deep lining of the trenches was left in place to prevent horizontal subsurface migration of adult infauna and to minimise disturbance. In this experiment, no survival of macrobenthic organisms was detected immediately after removal of the sheets, indicating complete defaunation of the macrofauna. The sediment was anoxic, containing high $\mathrm{NH}_{4}^{+}\left(51338 \mu \mathrm{g} \mathrm{l}^{-1}\right)$ and low $\mathrm{NO}_{3}^{-}$ $\left(2 \mathrm{\mu g} \mathrm{l}^{-1}\right)$ and $\mathrm{NO}_{2}^{-}\left(26 \mu \mathrm{g} \mathrm{l}^{-1}\right)$ pore water concentrations in the upper $\mathrm{cm}(14 \times, 8.4 \times, 17.9$, respectively, compared to the control sediment) and was characterised by a black surface.

Because recruitment by (post)larval macrobenthos was hypothesised to be the dominant colonisation mechanism at the experimental scale (Günther 1992), this experiment was conducted from 30 March until 30 September 2005, covering the macrobenthic peak recruitment period during spring and early summer. Environmental and biotic recovery was monitored 17 times (i.e. daily during the first $3 \mathrm{~d}$, then weekly during the first month and then biweekly until the end of the experiment). Moreover, to avoid disturbance in the plots due to sampling, samples were collected from a bridge, and sampling holes were filled with closed PVC tubes, pushed flush with the sediment surface. Furthermore, to minimise possible edge effects, sampling only occurred in the inner $3 \times 3 \mathrm{~m}$.

At each sampling day, 2 replicate subquadrats $(37.5 \times 37.5 \mathrm{~cm})$ per plot, never located next to each other, were randomly chosen beforehand. Depending on the response variable, 1 (macrofauna, organic matter, mud content and erosion threshold) or 2 (bed level, surface chlorophyll [chl] $a$, oxygen concentration, water content and nutrient pore water concentration) subquadrats were sampled in each plot.

Macrobenthos was sampled with a core (inner $\varnothing$ $12.5 \mathrm{~cm}$ ) to a depth of $40 \mathrm{~cm}$ and fixed with a neutralised $8 \%$ formalin solution. In the laboratory, the samples were sieved through a $0.5 \mathrm{~mm}$ mesh, and the residual was fixed and preserved using a neutralised
$4 \%$ formalin solution with $0.01 \%$ Rose Bengal until processing. All macrofauna was sorted, counted and identified to the species level, except for nematodes and tubificid oligochaetes. To distinguish between juvenile and adult individuals, population sizefrequency analysis was carried out for species present in all replicate samples after recruitment and with a mean abundance of $>30$ ind. sample ${ }^{-1}$ for either control or defaunated plots. This criterion was chosen to include only populations in which a representative size distribution and comparison between populations of control and defaunated plots could be ascertained. All size measurements were conducted using a stereo microscope fitted with an eyepiece graticule, except for larger bivalves, which were measured to the nearest $0.01 \mathrm{~mm}$ using a Vernier calliper.

The upper $1 \mathrm{~cm}$ of the sediment was sampled with a core (inner $\varnothing 6.3 \mathrm{~cm}$ for nutrient determination; inner $\varnothing 3.6 \mathrm{~cm}$ for all other variables), and immediately frozen $\left(-80^{\circ} \mathrm{C}\right.$ for samples used for pigment analysis, $-20^{\circ} \mathrm{C}$ for the other samples) awaiting analysis. These samples were analysed in the laboratory for granulometry using laser diffraction (Malvern Mastersizer 2000), water content (loss of mass after lyophilisation), total organic matter (loss on ignition at $500^{\circ} \mathrm{C}$ for $2 \mathrm{~h}$ ), total organic carbon and nitrogen (Element Analyser N1500, Carlo Erba) and photopigment concentration (HPLC analysis of the supernatant, extracted from the lyophilised sediment by adding $10 \mathrm{ml} 90 \%$ acetone). The chl a concentration ( $\mu \mathrm{g} \mathrm{g}^{-1}$ dry sediment) of the upper $3 \mathrm{~mm}$ of the sediment was used as a proxy for the microphytobenthos biomass (MPB biomass; Jeffrey et al. 1997). Separate cores (inner $\varnothing 3.6 \mathrm{~cm}$ ) containing $15 \mathrm{~cm}$ of sediment overlaid with seawater were carefully transported in a cold, dark container to the laboratory and incubated for $1 \mathrm{~d}$ in a controlled climate chamber (with approximately the same temperature as in the field) to measure a vertical sediment oxygen profile, using microelectrodes (OX 25, Unisense; $\mathrm{n}=$ 1 sample $^{-1}$ ). Ammonium pore water concentrations were determined (SAN ${ }^{\text {plus }}$ segmented flow analyser, SKALAR) and together with the oxygen measurements used to evaluate the oxidation status of the sediments. The sediment erosion threshold was measured in situ with a cohesive strength meter (CSM Mk III) and used as a proxy for sediment stability (Tolhurst et al. 1999). According to de Deckere et al. (2001), the critical erosion threshold was defined as the pressure at which transmission in the test chamber dropped below $90 \%$. Bed level elevation was determined ( $\mathrm{n}=3$ for each subquadrat) relative to a fixed reference point in the vicinity (i.e. measurement site by the Dutch National Institute for Coastal and Marine Management; RIKZ) and set to the Dutch Ordinance Level (NAP), using a rotating laser and receiving unit on a measuring pole. 
At the end of the experiment, $~ 50 \%$ of the surface was disturbed in both plot types due to sampling and subsequent scouring around the PVC tubes. However, additional sampling of the surrounding sediment did not indicate significant differences from the control plot sediments. As such, temporal variation of macrobenthos in the experimental plots was not largely affected by the repeated sampling.

Data analyses. Rare species (average maximum $<1$ ind. sample ${ }^{-1}$ in both plot types) and typical meio-, hyper- and epibenthic species were not taken into account for further analysis. Species were classified into functional groups according to their mobility, feeding guilds and burrowing activity (tube-building versus biodestabiliser) based on literature (e.g. Fauchauld \& Jumars 1979, Gerino et al. 2003, Volkenborn \& Reise 2007) and our own observations (Table A1 in Appendix 1).

Repeated measures analyses of variance (ANOVA; Green 1993) were conducted, in which Treatment and Time were fixed factors, to test the effect of Treatment (defaunated versus control) and Time (days after the start of the experiment) on community variables (macrobenthic abundance and biomass, juvenile abundance, species richness, Shannon-Wiener diversity index $H^{\prime}$ and Pielou's evenness index $J^{\prime}$ ). The same analysis was performed on the abundances of the species with an averaged abundance $>12$ ind. sample $^{-1}$ over both plot types during the experiment and the environmental variables MPB biomass and $\mathrm{NH}_{4}{ }^{+}$pore water concentration. Prior to analyses, the homogeneity of the variance-covariance structure (i.e. compound symmetry assumption) was analysed using the Mauchley test of sphericity, and Bartlett's and Cochran's tests were used to verify homogeneity of variances. Data not meeting these criteria were appropriately transformed. Replicated samples of variables per plot were pooled to avoid pseudoreplication (Hurlbert 1984). To determine relations in the temporal variation of biotic and environmental variables during succession and to relate temporal variation to the time of recovery, Pearson product-moment correlations were performed after the data were normalised. For variables that did not conform to a normal distribution, non-parametric Spearman-rank correlation test was used.

To investigate species reassembly and recovery status to control conditions, dissimilarities between and within species assemblages of control and defaunated plots for each sampling time were assessed by the similarities of percentage procedure (SIMPER, Clarke 1993). Prior to analysis the community abundance data were standardised square-root transformed using the Bray-Curtis index of similarity and visualised by nonmetric multi-dimensional scaling (MDS). Different assemblages, characterised by distinct changes in species and functional group dominance, were defined as successional assemblages (SAs), and species indicative of these SAs were determined by calculation of their indicator value (IV) using the INDVAL program (Dufrêne \& Legendre 1997). Further, relations between community reassembly and the environmental variables were assessed using the BIO-ENV routine (Clarke \& Gorley 2001). Prior to the BIO-ENV, environmental variables were appropriately transformed to gain normality and normalised to put them on a common, dimensionless measurement scale. Environmental variables that were not measured for each sampling time (oxygen penetration depth, sediment stability and bed level) were omitted for univariate and multivariate correlative analyses concerning the complete duration of the experiment. Statistical analyses were performed using Statistica 7.0 (Statsoft 1984-2004), the Plymouth routines in multivariate ecological research (PRIMER) package, version 5.2.9 (Clarke \& Gorley 2001). A significance level of $\mathrm{p}<0.05$ was used in all tests.

\section{RESULTS}

\section{Recolonisation and successional stages}

Repeated measures ANOVA revealed a significant Treatment $\times$ Time effect for the macrobenthic abundance and biomass, species richness, juvenile abundance, $H^{\prime}$ and $J^{\prime}$ (Fig. 1, Table 1). Both macrobenthic biomass and species richness were significantly related to the total time of recovery $\left(\mathrm{r}^{2}=0.85, \mathrm{p}<0.001\right.$; $\mathrm{r}^{2}=0.80, \mathrm{p}<0.001$, respectively). However, only species richness returned to control level at the end of the experiment, while biomass remained much lower. Diversity and evenness were high during the first $3 \mathrm{wk}$ of recovery, followed by a significant decrease. Both variables converged linearly towards control values at the end of the experiment $\left(r^{2}=0.84, p<0.001 ; r^{2}=0.84\right.$, $p<0.001$, respectively). Both total abundance and juvenile abundance first increased linearly $\left(\mathrm{r}^{2}=0.92\right.$, $\mathrm{p}<0.001 ; \mathrm{r}^{2}=0.99, \mathrm{p}<0.001$, respectively), achieving a peak abundance overshoot in the defaunated plots at $98 \mathrm{~d}$ after defaunation, followed by a linear decrease towards the end of the experiment $\left(r^{2}=0.89, p<0.001\right.$; $r^{2}=0.89, p<0.001$, respectively). Whereas macrobenthic abundance converged to control values after Day 98, juvenile abundance remained significantly higher than the controls.

Six species were considered sufficiently abundant for statistical analysis: in order of overall abundance, the annelids Pygospio elegans, Heteromastus filiformis, Aphelochaeta marioni, tubificid oligochaetes, the bivalve Macoma balthica and the annelid Nereis diversicolor, which, in total, comprised $\sim 85 \%$ of all individuals. A significant Treatment $\times$ Time effect was found for the abun- 


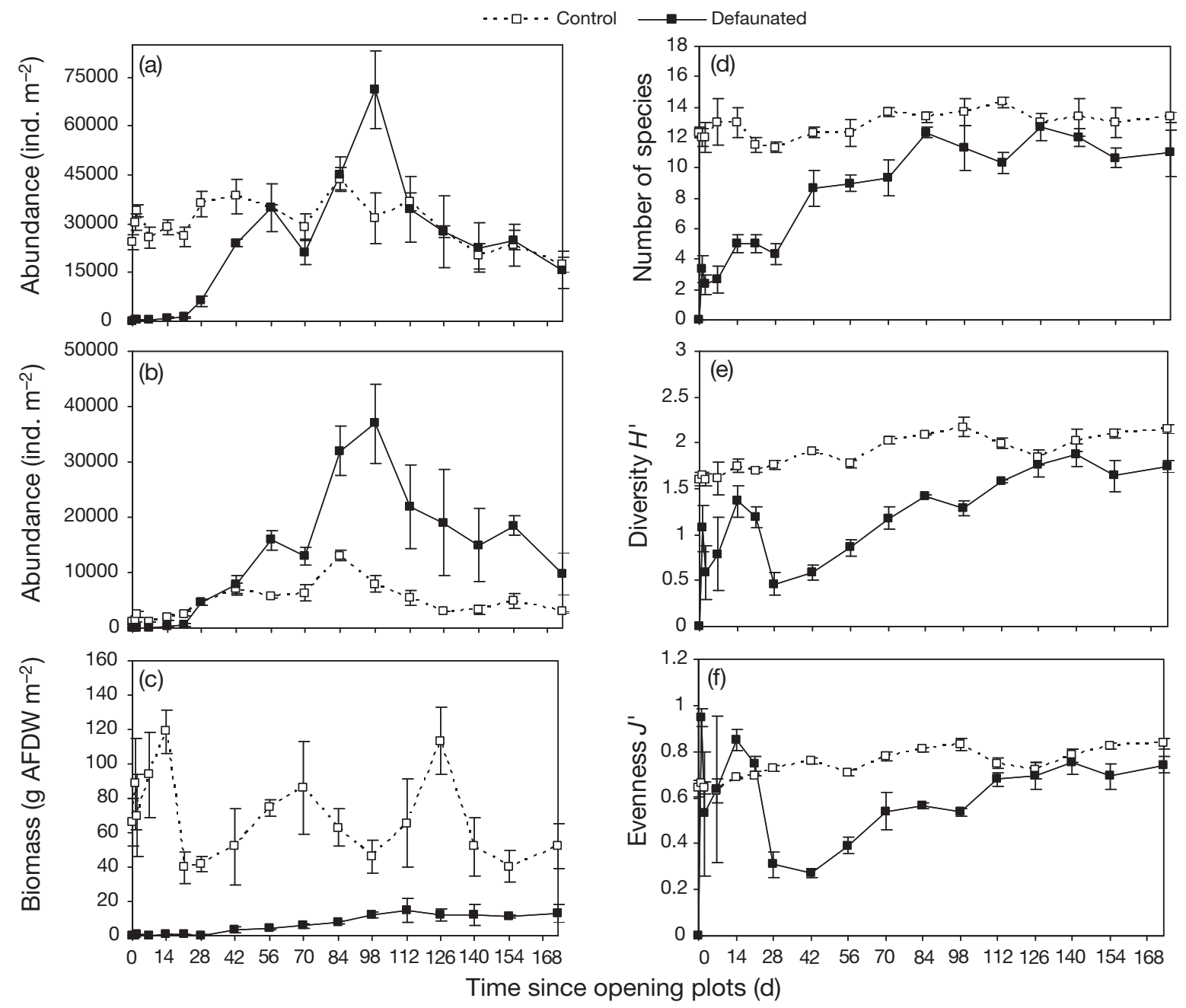

Fig. 1. Temporal variation of (a) total abundance, (b) total juvenile abundance, (c) total biomass, (d) number of species,

(e) Shannon-Wiener diversity and (f) Pielou's evenness in defaunated and control plots. Values are means $(n=3) \pm 1$ SE

Table 1. Repeated measures ANOVA results for the general univariate community variables, the 6 most abundant macrobenthic species, MPB biomass and $\mathrm{NH}_{4}{ }^{+}$pore water concentrations $(\mathrm{df}=1,16,16$ for Treatment, Time, Treatment $\times$ Time, respectively). Assumptions for compound symmetry (Mauchley test of sphericity; $\mathrm{p}>0.05$ ) and homogeneity of variances (Bartlett-Cochran test; $\mathrm{p}>0.05$ ) were met for all variables. -: no transformation performed

\begin{tabular}{|c|c|c|c|c|c|c|c|c|c|c|}
\hline & \multicolumn{3}{|c|}{ Treatment } & \multicolumn{3}{|c|}{ Time } & \multicolumn{3}{|c|}{ Treatment $\times$ Time } & \multirow[t]{2}{*}{ Transformation } \\
\hline & MS & $F$ & $\mathrm{p}$ & MS & $F$ & $\mathrm{p}$ & MS & $F$ & $\mathrm{p}$ & \\
\hline Species richness & 516.02 & 136.71 & 0.001 & 26.64 & 12.60 & $<0.001$ & 15.97 & 7.55 & $<0.001$ & - \\
\hline $\begin{array}{l}\text { Shannon-Wiener diversity } \\
\text { index } H^{\prime}\end{array}$ & 10.45 & 500.42 & $<0.001$ & 0.57 & 8.88 & $<0.001$ & 0.21 & 3.33 & 0.001 & - \\
\hline Pielou's eveness index $J^{\prime}$ & 0.72 & 20.97 & 0.020 & 0.06 & 3.14 & 0.001 & 0.05 & 2.43 & 0.009 & $\arcsin$-sqrt \\
\hline Macrobenthic abundance & 13.17 & 219.70 & 0.001 & 1.87 & 63.79 & $<0.001$ & 1.83 & 62.61 & $<0.001$ & $\log (x+1)$ \\
\hline Macrobenthic biomass & 28.36 & 514.01 & $<0.001$ & 0.26 & 7.73 & $<0.001$ & 0.29 & 8.77 & $<0.001$ & $\log (x+1)$ \\
\hline Juvenile abundance & 3.16 & 56.03 & 0.005 & 4.00 & 22.51 & $<0.001$ & 2.08 & 11.73 & $<0.001$ & $\log (x+1)$ \\
\hline Pygospio elegans & 2.66 & 11.22 & 0.044 & 3.71 & 16.65 & $<0.001$ & 2.64 & 11.85 & $<0.001$ & $\log (x+1)$ \\
\hline Nereis diversicolor & 12.36 & 19.27 & 0.022 & 20.28 & 34.14 & $<0.001$ & 9.17 & 15.44 & $<0.001$ & sqrt \\
\hline Macoma balthica & 107.62 & 64.07 & 0.004 & 18.00 & 30.39 & $<0.001$ & 15.04 & 25.38 & $<0.001$ & sqrt \\
\hline Heteromastus filiformis & 648.52 & 526.41 & $<0.001$ & 9.24 & 8.24 & $<0.001$ & 19.32 & 17.23 & $<0.001$ & sqrt \\
\hline Oligochaeta & 708.60 & 435.74 & $<0.001$ & 4.37 & 3.15 & 0.001 & 3.42 & 2.46 & 0.008 & sqrt \\
\hline Aphelochaeta marioni & 656.60 & 364.92 & $<0.001$ & 3.18 & 1.94 & 0.039 & 4.55 & 2.78 & 0.003 & sqrt \\
\hline MPB biomass & 299.52 & 10971.50 & 0.020 & 0.1870 & 11.73 & $<0.001$ & 0.1216 & 7.63 & $<0.001$ & $\arcsin$-sqrt \\
\hline Ammonium & $8.86 \times 10^{8}$ & 241.18 & 0.041 & $1.51 \times 10^{8}$ & 8 14.09 & $<0.001$ & $1.57 \times 10^{8}$ & 14.71 & $<0.001$ & - \\
\hline
\end{tabular}



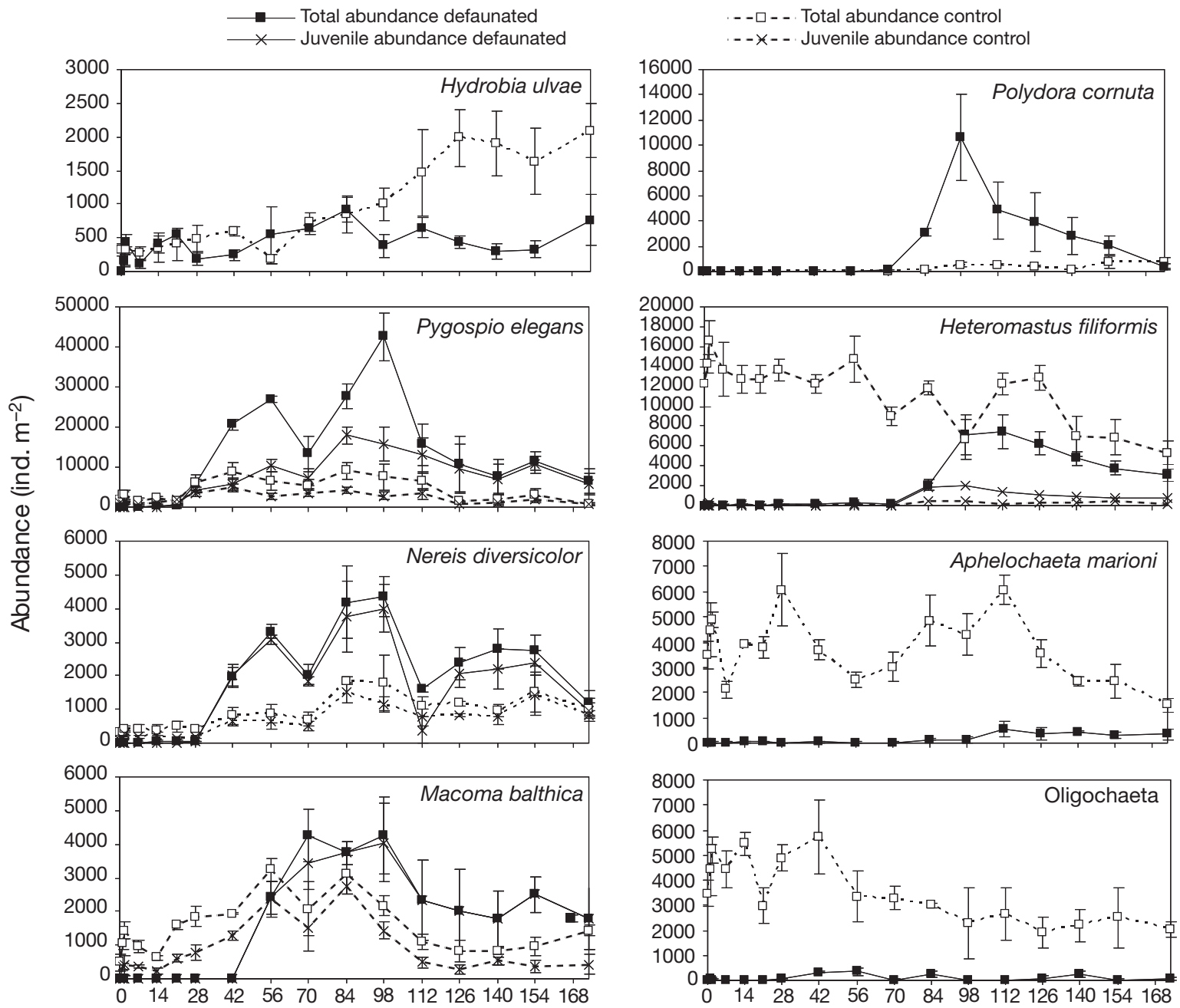

Time since opening plots $(d)$

Fig. 2. Hydrobia ulvae, Pygospio elegans, Nereis diversicolor, Macoma balthica, Polydora cornuta, Heteromastus filiformis, Aphelochaeta marioni, and Oligochaeta. Temporal variation in mean abundance $(\mathrm{n}=3) \pm 1$ SE in defaunated and control plots

dances of all of these species (Fig. 2, Table 1). Colonisation started with Hydrobia ulvae, followed by P. elegans, N. diversicolor, M. balthica and Polydora cornuta. The abundance of the latter 4 species exceeded the control values within the first 2 mo of recovery, reaching a maximal total abundance overshoot at Day 98 , followed by a significant decrease in abundance. Distinct colonisation of $H$. filiformis and A. marioni in the defaunated plots was only noticed from Day 98 onwards. Abundances of these 2 species never exceeded the control values during the experiment. Tubificid oligochaetes hardly colonised the defaunated plots at all. Colonisation of the defaunated plots was largely determined by juvenile recruitment, and, except for the first 3 wk of recovery, juvenile abundance was higher in the defaunated plots than in the controls (Fig. 1).

Multivariate analyses based on species abundances revealed that the species assemblage in the defau- nated plots evolved towards the control assemblages during the experiment (Fig. 3), but a dissimilarity of $\sim 27 \%$ between the species assemblages in both plot types still remained at the end of the experiment. Based on biomass, the dissimilarity was $\sim 49 \%$ at the end of the experiment (Table A2 in Appendix 1). Three successional stages, characterised by clear shifts in proportional abundance of species and functional group dominance were identified: 0 to 21,28 to 98 and 112 to $175 \mathrm{~d}$ after defaunation (Table A3, Fig. A1 in Appendix 1). During recovery, a shift in functional group dominance from mobile surface deposit feeders (Stage 1) to tube-dwelling surface deposit feeders (Stage 2) to biodestabilising taxa (Stage 3) occurred, while their proportional dominance remained more or less stable in the control plots throughout the experiment (Appendix 1, Fig. A1). Indicator species for the different species assemblages were Hydrobia ulvae 


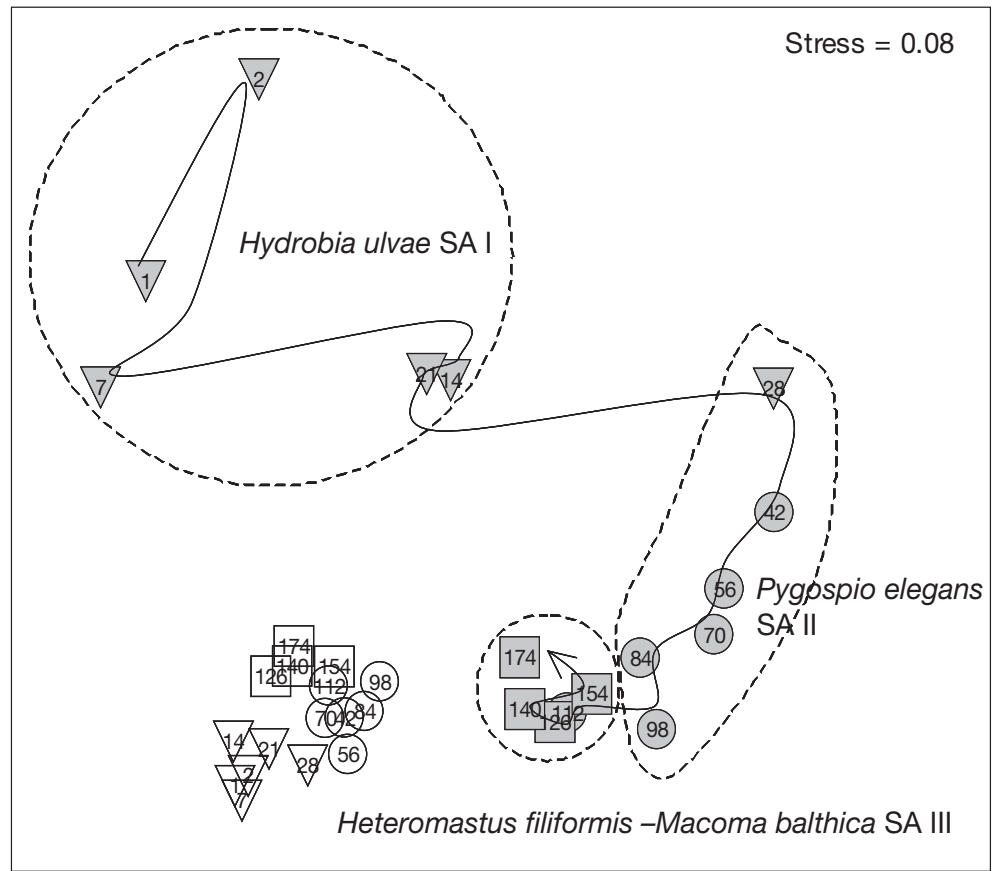

Fig. 3. Multi-dimensional scaling plots of species assemblages (SA) in defaunated and control plots over time based on Bray-Curtis similarities of standardised square-root abundance species data. Shading indicates treatments $($ grey $=$ defaunated; white $=$ control) and symbols indicate seasonality (triangles = March-April ; circles = May-July; squares = August September). Numbers are days after opening of the plots. The dashed lines indicate the defined successional assemblages

\section{Relationships between macrofauna and environmental variables}

Repeated measures ANOVA revealed a significant Treatment $\times$ Time effect for MPB biomass and $\mathrm{NH}_{4}{ }^{+}$concentration. Both variables also best explained the macrobenthic recolonisation pattern (BIO$\left.\mathrm{ENV}_{i} \rho=0.651\right)$. Adding other variables resulted in a lower correlation (e.g. mud content, water content, MPB biomass and $\mathrm{NH}_{4}{ }^{+}$concentration: $\left.\rho=0.606\right)$. Ammonium pore water concentrations, which were extremely high during Stage 1, recovered during successional Stage 3, while MPB biomass achieved control values already after $1 \mathrm{wk}$. MPB biomass further increased exponentially to Day 28, followed by a decrease towards Day 98, where control values were reached again (Fig. 4). During the period of exponential MPB growth, cooccurring with the first successional stage, the first macrobenthic species appeared in the defaunated plots. During the second successional stage, the increase of the later successional species Heteromastus filiformis and juvenile abundance were significantly positively related to the abundance of the indicator species Pygospio elegans $(\mathrm{r}=0.89, \mathrm{p}=0.017 ; \mathrm{r}=0.87, \mathrm{p}=$ 0.021 , respectively). MPB biomass de-

(SA I, IV = 53), Pygospio elegans (SA II, IV = 39.4), Macoma balthica (SA III, IV = 59.4) and Heteromastus filiformis (SA III, IV = 45.3). Furthermore, the steep decrease in total macrobenthic abundance, characterising the transition between successional Stages 2 and 3 , was numerically determined by the decrease of $P$. elegans, $M$. balthica and Nereis diversicolor; their decline accounted for $\sim 88 \%$ of the decrease in total abundance. creased during Stage 2 with the colonisation of surface deposit feeding populations and biodestabilising fauna ( $\mathrm{r}=-0.82, \mathrm{p}=0.042 ; \mathrm{r}=-0.83, \mathrm{p}=0.040$, respectively).

Furthermore, the sediment was more stable during Stage 2 as compared to Stage 3 (Fig. 5, Montserrat et al. 2008 , this volume). The decrease in sediment stability content during the second and third stage was correlated with the colonisation of Heteromastus filiformis, an indicator species for SA III $(r=-0.77, \mathrm{p}=0.006)$ and
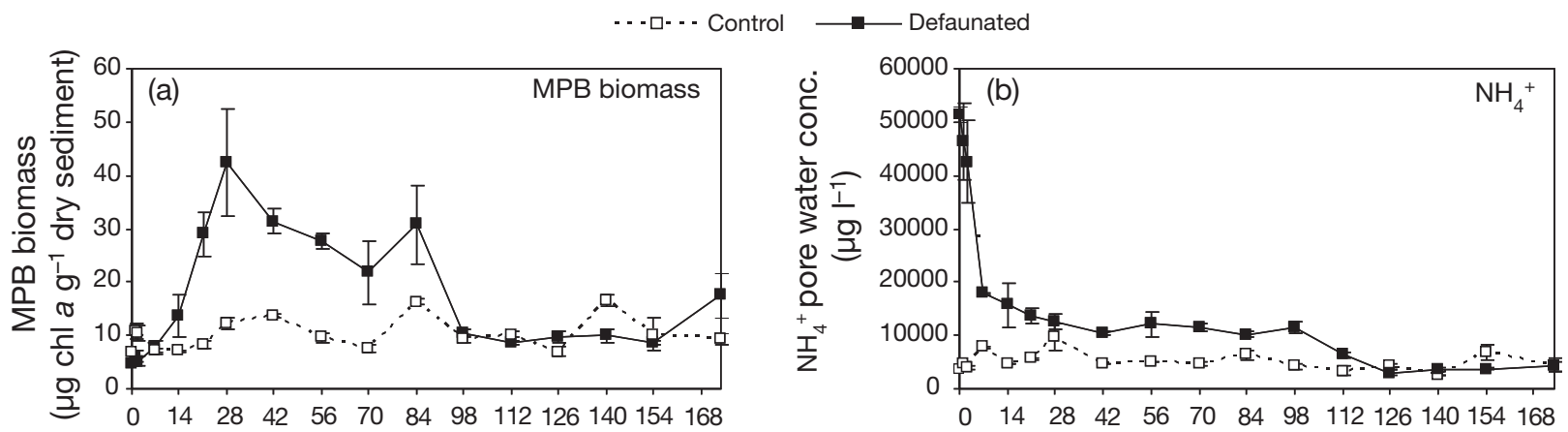

Time since opening plots $(d)$

Fig. 4. Temporal variation in (a) microphytobenthos (MPB) biomass ( $\mu \mathrm{g}$ chl a g${ }^{-1}$ dry sediment) and (b) $\mathrm{NH}_{4}{ }^{+}$pore water concentration. Means $(n=3) \pm 1$ SE in both defaunated and control plots 
- - (a) Relative abundance motile fauna; (b) $\mathrm{NH}_{4}^{+}$(a) Relative abundance tube-building fauna; (b) Sediment stability

(a) Total abundance surface deposit feeding fauna; (b) Chl a

- - - (a) Total biomass biodestabilizing fauna; (b) Oxygen penetration depth
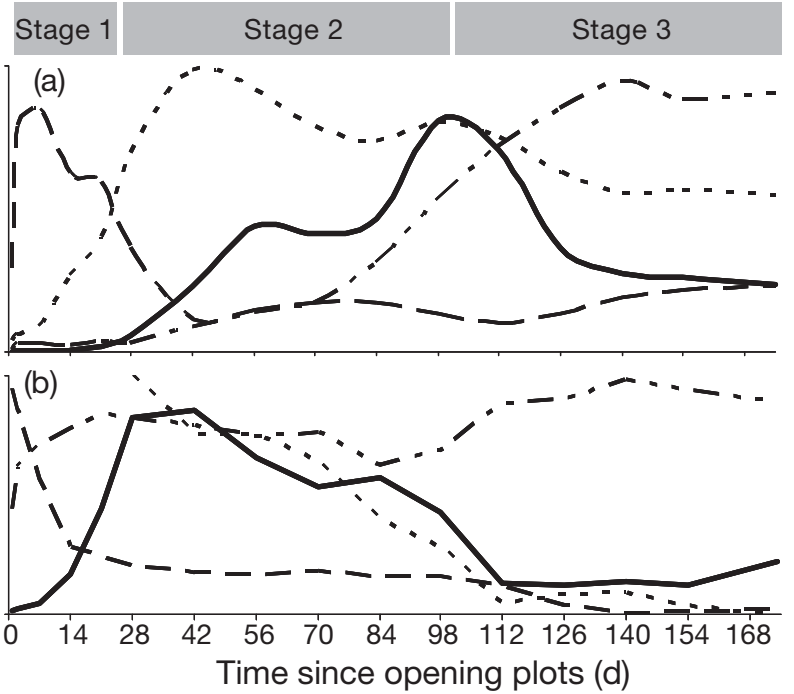

Fig. 5. (a) Temporal variation of surface deposit feeding population abundance, biomass of biodestabilising populations, relative abundance of tube-building populations and motile infauna populations during succession. (b) Temporal variation of microphytobenthos biomass, sediment stability, oxygen penetration depth and ammonium concentration. Curve fits are running averages (period $=2$ sampling occasions) through normalised data. Exact data for the variables presented are given in Fig. 4, Fig. A1 (Appendix 1) and Montserrat et al. (2008, this volume)

increase in the biomass of the biodestabilising infauna, in general $(r=-0.66, p=0.033)$. Successional Stage 3 was characterised by more oxygenated sediments comparable to control values, indicated by deeper oxygen penetration and lower ammonium concentrations in the upper sediment layer (Figs. 4 \& 5). The decline in $\mathrm{NH}_{4}{ }^{+}$ pore water concentrations during recovery was related to the increase in biomass of biodestabilising macrobenthos $(\mathrm{r}=-0.91, \mathrm{p}<0.001)$ and $H$. filiformis in particular $(\mathrm{r}=-0.97, \mathrm{p}<0.001)$.

\section{DISCUSSION}

\section{Recovery}

Our study did not demonstrate complete recovery or 'steady state' of succession, which would have required a high similarity to the control assemblage in terms of species abundance and biomass.

Recovery rate is dependent on the scale of disturbance in intertidal habitats (Zajac et al. 1998, Norkko et al. 2006). Fast adult migration is the predominant recovery mechanism at smaller scales $\left(<1 \mathrm{~m}^{2}\right)$, while colonisation of large-scale disturbed habitats is initiated and dominated by post-larval and juvenile recruitment (Günther 1992). Due to the scale of disturbance, and the careful avoiding of lateral subsurface movement of adults in the plots, our study therefore focused on recovery mechanisms determined by juvenile recruitment. According to Beukema et al. (1999), complete recovery at the community level at larger scales can last several years. Furthermore, any estimate of the recovery time depends on the criteria used. In this study, the total macrobenthic density was restored within $42 \mathrm{~d}$ after defaunation, while diversity measurements (species richness, $H^{\prime}, J^{\prime}$ ) required a longer period to recover. Similar recovery times have been reported by Dittmann et al. (1999) in a large-scale study performed in an intertidal sandflat.

In this study, a clear Pearson-Rosenberg type succession sequence, including a peak abundance overshoot by opportunists, was found, and the macrobenthos recovery trajectory could generally be divided into 3 successional stages, characterised by different species assemblages and distinct environmental characteristics. Furthermore, no turnover of species was observed, i.e. all species remained in the communities throughout the recorded successional period. Hence, early succession in intertidal mudflats should be interpreted in terms of increases and decreases of species dominance.

\section{Successional stages and transitions}

A conceptual scheme presenting the hypothesised interactions during this recovery study is given in Fig. 6. These interactions are based on significant relationships of both environmental and biotic variables and often contemporaneous shifts of these variables between the successional stages. However, we want to point out that relationships do not necessarily imply causality. Therefore, manipulative species interactions are required to investigate the driving processes of succession. The interactions presented in Fig. 6 enable targeted research regarding the driving interactions of macrobenthos succession in tidal mudflats.

\section{Stage 1}

Hydrobia ulvae dominated the community during the first stage, but abundance overshoots were not observed. This species is a mobile, grazing mudsnail that can cover large distances by crawling over the sediment and passive 'rafting' during flooding (Haubois et al. 2002). Consequently, this species may be considered a good coloniser. Colonisation by $H$. 


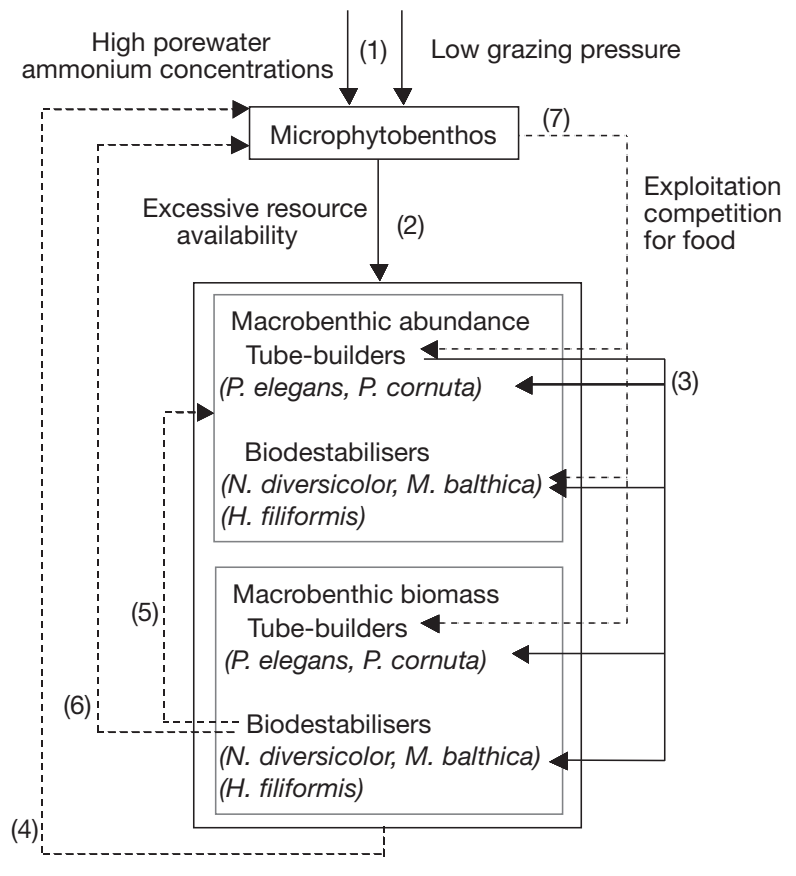

Grazing pressure of surface deposit feeding populations

Fig. 6. Schematic representation of the hypothesised facilitative (solid lines) and inhibitory (dashed lines) interactions during this succession study. Following defaunation resulting from hypoxia, the low grazing pressure of surface deposit feeding populations and the high pore water ammonium concentrations enhance microphytobenthic development at early successional stages (1; excessive resource availability), which, in turn, facilitates the recruitment of juvenile tubebuilding and biodestabilising macrofauna during successional Stage 2 (2). Tube-builders enhance macrobenthic recruitment success by protecting the sediment from erosion due to the production of skimming flow (3). This results in an enhanced grazing pressure of surface deposit feeders, consuming the microphytobenthos (4). At later succession stages, biomass of biodestabilising fauna has increased, enhancing their bioturbation impact, which, in turn, counteracts the favourable conditions provided by the tube-builders (5) and microphytobenthic development (6). Exploitation competition for food results in the demise of surface deposit feeding population abundances and the biomass of tube-builders (7). Key species governing the interactions are presented in parentheses (see Fig. 2 for full species names)

ulvae was determined by adult immigration. In general, juvenile recruitment did not occur until Day 28 in the defaunated plots, although some juvenile recruitment occurred in the controls during the same period. The more anoxic situation during the first 4 wk of recovery likely inhibited juvenile recruitment of later successional species and opportunistic behaviour of $H$. ulvae. Especially, ammonium pore water concentrations in the upper sediment layer were high during the first week of recovery compared to the control values. This high level of reduced nitrogen resulted from the defaunation technique, in which bio-irrigation of the bottom was inhibited. Decreased juvenile macroben- thic recruitment and settling success have been found in anoxic and suboxic sediments (Marinelli \& Woodin 2002, Engstrom \& Marinelli 2005). Further, successional Stage 1 was determined by the exponential development of a microphytobenthic mat. This is in accordance with Daborn et al. (1993) and is suggested to be the result of the low abundance of grazers and the high pore water nutrient concentrations during Stage 1 compared to the control plots. Furthermore, $H$. ulvae abundance and biomass were not significantly related to abiotic or biotic variables during the first stage, suggesting that this early coloniser, which is present in relatively low numbers, has no clear effect on subsequent colonisers or changing environmental conditions. Therefore, the transition between successional Stages 1 and 2 is presumably related to the changes in oxygen characteristics of the sediment and peak recruitment of Pygospio elegans, an indicator species for SA II.

\section{Stages 2 and 3}

Successional Stage 2 was characterised by the dense microphytobenthic mat and by abundant immigration of juveniles of several macrobenthic species. Enhanced juvenile recruitment has often been noted in marine biofilms and is hypothesised to be the result of both inductive species-specific responses to the bacterial composition of the biofilm (reviewed by Rodriguez et al. 1993) and a lower post-settlement mortality due to food limitation (Ólafsson et al. 1994, Gosselin \& Qian 1997). The surface deposit feeding species Pygospio elegans, Macoma balthica, Polydora cornuta and the omnivore Nereis diversicolor showed an opportunistic response, i.e. abundance overshoot followed by a steep decline and faster growth (data not shown) compared to the ambient sediments. The higher recruitment success of juveniles in the defaunated plots compared to the controls was related to the higher abundance of tube-building polychaetes ( $P$. elegans and $P$. cornuta). $P$. elegans and $P$. cornuta are small, sedentary, tubebuilding polychaetes with a wide habitat tolerance, a variety of feeding mechanisms and a remarkable diversity of reproductive strategies (Anger et al. 1986, Zajac 1991, Bolam \& Fernandes 2002). Therefore, these species are capable of rapidly colonising disturbed areas and using new resources rapidly. Both species reached high abundances (i.e. 5.6× and $19.5 \times$ control values on Day 98, respectively, for $P$. elegans and $P$. cornuta) during Stage 2. Adverse effects of the dense tube aggregations on juvenile settling, either indirectly or through predation, are possible (Cummings et al. 1996) but are presumably covered up by their facilitative effects in the defaunated plots. Poly- 
chaete tubes exert profound effects on near-bed flow, which above a certain threshold abundance leads to sediment stabilisation where passive deposition of larvae or juveniles is enhanced (Eckman 1983, Friedrichs et al. 2000). The sediment stability data confirm the higher stability of the sediments in the defaunated plots during the period of high $P$. elegans abundance (i.e. successional Stage 2; Fig. 5, Montserrat et al. 2008). Furthermore, polychaete tubes have been suggested to provide a refuge from disturbance and predation to larvae and juveniles (Gallagher et al. 1983). In this study, the control sediments experienced a net erosion of $3.4 \mathrm{~cm}$ during successional Stage 2 while sediment bed level elevation remained stable in the defaunated plots. This was related to the abundance of $P$. elegans and their enhanced effect of mud particle retainment (Montserrat et al. 2008). Moreover, dense aggregations of polychaete tubes have been found to increase food availability indirectly, which is hypothesised to result from biogeochemical bio-irrigation impacts of the tubes (Brey 1991, Bolam \& Fernandes 2002, references therein).

Inhibitory adult-juvenile interactions structure juvenile recruitment in marine soft-bottom habitats. For instance, large biodestabilising macrofauna adversely effect juvenile recruitment success directly (e.g. by predation; Hiddink et al. 2002) and/or indirectly (e.g. by destabilisation of the sediment, inhibition of microphytobenthos development, competition for space; Ólafsson 1989, Ólafsson et al. 1994, Flach 2003). Therefore, enhanced juvenile recruitment to the defaunated plots is presumably also related to the lower biomass of destabilising infauna in the defaunated plots. One species, the common cockle Cerastoderma edule, largely contributed to the average difference in biomass between the defaunated and control species assemblage throughout the experiment (Table A3 in Appendix 1). Flach (1996) showed a severe negative effect of $C$. edule densities on juvenile recruitment, thereby largely influencing the macrobenthic community in tidal flats in the Wadden Sea. The absence of large $C$. edule in the defaunated plots in this study is in accordance with the study of Beukema et al. (1999). The time to complete restoration of ambient age distributions of $C$. edule, and thus biomass, may be expected to be as long as the life-span of the cockle. In summary, the enhanced macrobenthic recruitment of later successional species (i.e. Nereis diversicolor, Polydora ligni, Macoma balthica) in the defaunated plots during Stage 2 is presumably related to (1) the increased passive larval settling, lower postsettlement mortality and dispersal due to the created favourable conditions within the dense Pygospio elegans patches and (2) the low biomass of large biodestabilising organisms (i.e. C. edule).
The transition between successional Stages 2 and 3 coincided with (1) the decline in resource availability, i.e. MPB biomass, immediately followed by the decrease in surface deposit feeder abundance and (2) the take-over in biomass dominance of destabilising omnivores/scavengers (i.e. Nereis diversicolor), surface deposit feeders (i.e. Macoma balthica) and subsurface deposit feeders (Heteromastus filiformis). The decrease in MPB biomass was related to the increase of surface deposit feeders, suggesting that the take-over is regulated by direct exploitation competition for food. This trophic group achieved a maximal abundance overshoot of 58481 ind. $\mathrm{m}^{-2}$ on Day 98 (i.e. $6.5 \times$ control values) and thereby possibly reached the ecological carrying capacity for its populations. However, indirect effects on resource availability caused by $H$. filiformis, an indicator species for successional SA III, cannot be excluded. H. filiformis is a subsurface deposit conveyer belt feeding polychaete that produces very resistant faecal pellets on the sediment surface (Cadée 1979, authors' pers. obs.). At high densities these pellets may decrease primary productivity by covering the sediment surface, resulting in a lowered MPB biomass. Furthermore, the contemporaneous decrease in sediment stability along with the increase in biomass of biodestabilising species suggest that the colonisation of $H$. filiformis, together with the growth of $N$. diversicolor and M. balthica, counteracted the favourable, stable conditions provided by the tube-dwelling infauna during successional Stage 2. These results are consistent with Bolam \& Fernandes (2002), who found that the demise of dense Pygospio elegans patches coincided with a dramatic increase in the abundance of 2 biodestabilising bivalve species ( $M$. balthica and Cerastoderma edule). Taken together, we suggest that the transition in species assemblages between successional Stages 2 and 3 is triggered both by exploitation competition for food and the bioengineering impact on the sediment characteristics of $H$. filiformis, and by biodestabilising fauna in general, during successional Stage 3.

In general, our study suggests that macrobenthic reassembly after hypoxia is related to different types of interactions. Macrobenthic successional dynamics in a defaunated tidal mudflat habitat should be considered as a dynamic process, related to resource availability, natural temporal variation, life history traits (e.g. opportunistic behaviour) and bio-engineering capacities of the colonising species.

Acknowledgements. This research was supported by the Institute for the Promotion of Innovation through Science and Technology in Flanders, Belgium (IWT Vlaanderen), the Dutch Technology Foundation STW, applied sciences division of NWO and the Technology Program of the Ministry of Eco- 
nomic Affairs. We thank D. Van Gansbeke, D. Schram, M. Houtekamer, C. Kleppe, H. Francke and Y. van der Maas for their assistance during the processing of the samples, as well as B. Beuselinck, D. Peelaers, J. van Soelen and B. Koutstaal for their help during sampling. $\mathrm{M}$. Vos and 3 anonymous reviewers provided valuable comments and advice on the manuscript. This paper contributes to the Ghent University BBSea Project (GOA 01600705) and the EU Network of Excellence MarBEF (GOCE-CT-2003-505446). This is contribution number 8040 of Marbef and NIOO-KNAW 4373.

\section{LITERATURE CITED}

Anger K, Anger V, Hagmeier E (1986) Laboratory studies on the larval growth of Polydora ligni, Polydora ciliata and Pygospio elegans (Polychaeta, Spionidae). Helgol Wiss Meeresunters 40:377-395

Benedetti-Cecchi L (2000) Predicting direct and indirect interactions during succession in a mid-littoral rocky shore assemblage. Ecol Monogr 70:45-72

Beukema JJ, Cadée GC (1996) Consequences of the sudden removal of nearly all mussels and cockles from the Dutch Wadden Sea. PSZN I: Mar Ecol 17:279-289

Beukema JJ, Flach EC, Dekker R, Starink M (1999) A long term study of the recovery of the macrozoobenthos on large defaunated plots on a tidal flat in the Wadden Sea. J Sea Res 42:235-254

Bolam SG, Fernandes TF (2002) Dense aggregations of tubebuilding polychaetes: response to small-scale disturbances. J Exp Mar Biol Ecol 269:197-222

> Bolam SG, Fernandes TF (2003) Dense aggregations of Pygospio elegans (Claparède): effect on macrofaunal community structure and sediments. J Sea Res 49:171-185

Bolam SG, Whomersley P, Schratzberger M (2004) Macrofaunal recolonization on intertidal mudflats: effect of sediment organic and sand content. J Exp Mar Biol Ecol 306: $157-180$

- Brey T (1991) Interactions in soft bottom benthic communities: quantitative aspects of behaviour in the surface deposit feeders Pygospio elegans (Polychaeta) and Macoma balthica (Bivalvia). Helgol Wiss Meeresunters 45:301-316

Cadée GC (1979) Sediment reworking by the polychaete Heteromastus filiformis on a tidal flat in the Dutch Wadden Sea. Neth J Sea Res 13:441-456

> Clarke KR (1993) Non-parametric multivariate analysis of changes in community structure. Aust J Ecol 18:117-143

Clarke KR, Gorley RN 2001. Primer v5: user manual/tutorial. Primer-E, Plymouth Marine Laboratory, Plymouth

> Cloern JE (2001) Our evolving conceptual model of the coastal eutrophication problem. Mar Ecol Prog Ser 210: 223-253

Connell JH, Slatyer RB (1977) Mechanisms of succession in natural communities and their role in community stability and organization. Am Nat 111:1119-1144

Cummings VJ, Pridmore RD, Thrush SF, Hewitt HE (1996) Effect of the spionid polychaete Broccardia syrtis on the distribution and survival of juvenile Macomona liliana (Bivalvia: Tellinacea). Mar Biol 126:91-98

Daborn GR, Amos CL, Brylinski H, Drapeau G and others (1993) An ecological cascade effect: migratory birds affect stability of intertidal sediments. Limnol Oceanogr 38: 225-231

> de Deckere EMGT, Tolhurst TJ, de Brouwer JFC (2001) Destabilization of cohesive intertidal sediments by infauna. Estuar Coast Shelf Sci 53:665-669

Diaz RJ, Rosenberg R (1995) Marine benthic hypoxia: a review of its ecological effects and the behavioural responses of benthic macrofauna. Oceanogr Mar Biol Annu Rev 33:245-303

Dittmann S, Günther CP, Schleier U 1999. Recolonization of tidal flats after disturbance. In: Dittmann S (ed) The Wadden Sea ecosystem: stability, problems and mechanisms. Springer, Berlin, p 175-192

Dufrêne M, Legendre P (1997) Species assemblages and indicator species: the need for a flexible asymmetrical approach. Ecol Monogr 67:345-366

Eckman JE (1983) Hydrodynamic processes affecting benthic recruitment. Limnol Oceanogr 28:241-257

> Engstrom SJ, Marinelli RL (2005) Recruitment responses of benthic infauna to manipulated sediment geochemical properties in natural flows. J Mar Res 63:407-437

Fauchauld K, Jumars PA (1979) The diet of worms: a study of polychaete feeding guilds. Oceanogr Mar Biol Annu Rev $17: 193-284$

Flach EC (1996) The influence of the cockle, Cerastoderma edule, on the macrobenthic community of tidal flats in the Wadden Sea. PSZN I: Mar Ecol 17:87-98

Flach EC (2003) The separate and combined effects of epibenthic predation and presence of macro-infauna on the recruitment success of bivalves in shallow soft-bottom areas on the Swedish west coast. J Sea Res 49:59-67

Friedrichs M, Graf G, Springer B (2000) Skimming flow induced over a simulated polychaete tube lawn at low population densities. Mar Ecol Prog Ser 192:219-228

Gallagher ED, Jumars PA, Trueblood DD (1983) Facilitation of soft-bottom benthic succession by tube builders. Ecology 64:1200-1216

Gerino M, Stora G, Francois-Carcaillet F, Gilbert F and others (2003) Macro-invertebrate functional groups in freshwater and marine sediments: a common mechanistic classification. Vie Milieu 53:221-231

> Gosselin LA, Qian PY (1997) Juvenile mortality in benthic marine invertebrates. Mar Ecol Prog Ser 146:265-282

> Green RH (1993) Application of repeated measures designs in environmental impact and monitoring studies. Aust J Ecol 18:81-98

Günther CP (1992) Dispersal of intertidal invertebrates: a strategy to react to disturbances of different scales? Neth J Sea Res 30:45-56

Hampel H, Cattrijsse A, Mees J (2004) Changes in marsh nekton communities along the salinity gradient of the Schelde River, Belgium and The Netherlands. Hydrobiologia 515: 137-146

> Haubois AG, Guarini JM, Richard P, Blanchard GF, Sauriau PG (2002) Spatio-temporal differentiation in the population structure of Hydrobia ulvae on an intertidal mudflat (Marennes-Oleron Bay, France). J Mar Biol Assoc UK 82: 605-614

Herman PMJ, Middelburg JJ, Van De Koppel J, Heip CHR (1999) Ecology of estuarine macrobenthos. Adv Ecol Res 29:195-240

Herman PMJ, Middelburg JJ, Heip CHR (2001) Benthic community structure and sediment processes on an intertidal flat: results from the ECOFLAT project. Cont Shelf Res 21: 2055-2071

Hiddink JG, ter Hofstede R, Wolff WJ (2002) Predation of intertidal infauna on juveniles of the bivalve Macoma balthica. J Sea Res 47:141-159

> Hurlbert SH (1984) Pseudoreplication and design of ecological field experiments. Ecol Monogr 54:187-211

Jeffrey SW, Mantoura RFC, Wright SW 1997. Phytoplankton pigments in oceanography. United Nations Educational and Scientific Organization, Paris 
Lenihan HS, Peterson $\mathrm{CH}$, Kim SL, Conclan KE and others (2003) Variation in marine benthic community composition allows discrimination of multiple stressors. Mar Ecol Prog Ser 261:63-73

Lindeboom $\mathrm{H}$ 2002. The coastal zone: an ecosystem under pressure. In: Field JG, Hampel G, Summerhayes C (eds) Oceans 2020: science, trends and the challenge of sustainability. Island Press, Washington, DC, p 49-84

Marinelli RL, Woodin SA (2002) Experimental evidence for linkages between infaunal recruitment, disturbance and sediment surface chemistry. Limnol Oceanogr 47:221-229

Montserrat F, Van Colen C, Degraer S, Ysebaert T, Herman PMJ (2008) Benthic community-mediated sediment dynamics. Mar Ecol Prog Ser 372:43-59

Newell RC, Seiderer LJ, Hitchcock DR (1998) The impact of dredging works in coastal waters: a review of the sensitivity to disturbance and subsequent recovery of biological resources on the seabed. Oceanogr Mar Biol Annu Rev 36: $127-178$

Norkko A, Rosenberg R, Thrush SF, Whitlatch RB (2006) Scale- and intensity-dependent disturbance determines the magnitude of opportunistic response. J Exp Mar Biol Ecol 330:195-207

Ólafsson EB (1989) Contrasting influences of suspensionfeeding and deposit-feeding populations of Macoma balthica on infaunal recruitment. Mar Ecol Prog Ser 55: 171-179

Ólafsson EB, Peterson CH, Ambrose WG (1994) Does recruitment limitation structure populations and communities of macro-invertebrates in marine soft sediments: the relative significance of pre- and post-settlement processes. Oceanogr Mar Biol Annu Rev 32:65-109

Paterson DM, Black KS (1999) Water flow, sediment dynamics and benthic biology. Adv Ecol Res 29:155-193

Pearson TH, Rosenberg R (1978) Macrobenthic succession in relation to organic enrichment and pollution of the marine environment. Oceanogr Mar Biol Annu Rev 16:229-311

Rodríguez SR, Ojeda FP, Inestrosa NC (1993) Settlement of benthic marine invertebrates. Mar Ecol Prog Ser 97: 193-207

Thrush SF, Dayton PK (2002) Disturbance to marine benthic habitats by trawling and dredging: implications for marine

Editorial responsibility: Lisandro Benedetti-Cecchi, Pisa, Italy biodiversity. Annu Rev Ecol Syst 33:449-473

Thrush SF, Pridmore RD, Hewitt JE, Cummings VJ (1992) Adult infauna as facilitators of colonization on intertidal sandflats. J Exp Mar Biol Ecol 159:253-265

Thrush SF, Whitlatch RB, Pridmore RD, Hewitt JE, Cummings VJ, Wilkinson MR (1996) Scale-dependent recolonization: the role of sediment stability in a dynamic sandflat habitat. Ecology 77:2472-2487

Tolhurst TJ, Black KS, Shayler SA, Mather S, Black I, Baker K, Paterson DM (1999) Measuring the in situ erosion shear stress of intertidal sediments with the Cohesive Strength Meter (CSM). Estuar Coast Shelf Sci 49:281-294

> Van Colen C, Vincx M, Degraer S (2006) Does medium-term emersion cause a mass extinction of tidal flat macrobenthos? The case of the Tricolor oil pollution prevention in the Zwin nature reserve (Belgium and The Netherlands). Estuar Coast Shelf Sci 68:343-347

> Van Wesenbeeck BK, van de Koppel J, Herman PMJ, Bakker JP, Bouma TJ (2007) Biomechanical warfare in ecology: negative interactions between species by habitat modification. Oikos 116:742-750

Volkenborn N, Reise K (2007) Effects of Arenicola marina on polychaete functional diversity revealed by large-scale experimental lugworm exclusion. J Sea Res 57:78-88

Whitlatch RB, Zajac RN (1985) Biotic interactions among estuarine infaunal opportunistic species. Mar Ecol Prog Ser 21:299-311

Wootton JT (2002) Mechanisms of successional dynamics: consumers and the rise and fall of species dominance. Ecol Res 17:249-260

Ysebaert T, Herman PMJ, Meire P, Craeymeersch J, Verbeek H, Heip CHR (2003) Large-scale spatial patterns in estuaries: estuarine macrobenthic communities in the Schelde estuary, NW Europe. Estuar Coast Shelf Sci 57:335-355

Zajac RN (1991) Population ecology of Polydora ligni (Polychaeta: Spionidae). I. Seasonal variation in population characteristics and reproductive activity. Mar Ecol Prog Ser 77:197-206

Zajac RN, Whitlatch RB, Thrush SF (1998) Recolonization and succession in soft-sediment infaunal communities: the scale of controlling factors. Hydrobiologia 375-376: $227-240$

Submitted: January 25, 2008; Accepted: July 4, 2008

Proofs received from author(s): October 30, 2008 